\title{
Effects of Variable Food Supply on the Body Condition of Breeding Tawny Owls Strix aluco in Southern Finland
}

\author{
Tapio Solonen \\ Luontotutkimus Solonen Oy, Neitsytsaarentie $7 b$ B 147, 00960 Helsinki, Finland \\ Correspondence should be addressed to Tapio Solonen, tapio.solonen@pp.inet.fi \\ Received 20 January 2011; Accepted 15 March 2011 \\ Academic Editor: U. Shanas \\ Copyright () 2011 Tapio Solonen. This is an open access article distributed under the Creative Commons Attribution License, \\ which permits unrestricted use, distribution, and reproduction in any medium, provided the original work is properly cited. \\ Body condition of boreal species of vole-eaters seems to vary in accordance with fluctuating vole populations. Tawny owls Strix \\ aluco of temperate origin were studied to reveal if they show a similar pattern during nestling period near the northern limit \\ of the species' range. The body condition of tawny owls was not considerably affected by the annual fluctuations of small voles \\ indicated by regional vole indices and local prey samples. There were some significant relationships with some alternative prey but \\ the variation in the body condition of owls was largely explained by the bird's age, time of the season, and stage of the nestling \\ period. Old birds that bred earlier in the season were in better condition than young ones that bred later. Due to alternative prey, \\ the body condition seemed to be relatively resistant to the effects of variable foraging conditions as expected for a generalist species \\ of southern origin.
}

\section{Introduction}

Body condition can be defined as a physiological state in terms of allocations of protein and lipid [1,2]. Increases in lipid reserves require corresponding increases in structural protein, and fitness is maximized by some optimal ratio of lipid and protein reserves. In birds, in general, it is thought that "fat is fit" [3], but the optimal ratio of lipid and protein reserves may vary across taxa, or cross-seasonally within taxa [1]. It has been suggested that as far as only unverified indices are available species- and sex-specific body mass seemed to be a proper indicator of body condition [2].

Sufficient food supply is essential for accomplishing body condition needed for the commencement and successful realisation of breeding in birds [4]. Birds of prey are capital breeders that acquire their resources in advance and store them until they are needed to supply aspects of offspring production $[5,6]$. The sufficiency of their body condition for breeding seems to be largely determined by the foraging conditions during the months immediately preceding the onset of egg laying $[7,8]$. The main strategies to overcome the negative effects of variable food supply are (1) to follow the abundance of the staple prey spatially (nomadic specialists), (2) when necessary, to rely on some alternative prey (stationary generalists), or (3) to abandon breeding altogether [9-12].

Because of the prominent division of roles in breeding birds of prey, larger-sized females are dependent on the feeding of smaller-sized males that bring them food before and during the early stages of breeding [13-17]. Large body size (and large fat reserves) should be advantageous for females defending the nest and brood, while small size (and relatively small fat reserves) should improve agility and foraging capacity in males [18]. A decisive limit for the initiation of egg laying is probably set by the foraging capacity of the male. When food is scanty, the male may be unable to catch enough prey for keeping its body mass normal, and it may be hard to fatten the female to acquire breeding condition. During breeding, the body condition of females is constrained by clutch size and incubation as well as by the general availability of prey and the foraging capacity of the male [19]. Body condition of males is affected by the general availability of prey and by brood size, according to the workload needed to fulfil the energy requirements of the male itself as well as those of the female and young. In any case, in general, the body mass seems to decline during breeding with increasing energy demands $[4,14,20,21]$. 
Body mass of birds also show seasonal and annual variations that seem to follow fluctuations in abundance of their staple prey. In Europe, the southern populations of vole-eaters, for example, common kestrels Falco tinnunculus $[22,23]$ and tawny owls Strix aluco [7], show, in general, relatively minor annual variations in body mass, characterising the relatively stable prey base of the region [24] and generalist foraging habits of the species [25]. Between seasons of year, however, variations may be considerable [17, 23]. In northern species that largely rely on highly fluctuating populations of small voles (Myodes spp., Microtus spp.) as their staple prey, such as the largely nomadic Tengmalm's owl Aegolius funereus [8] and the highly sedentary Ural owl Strix uralensis [20], the body mass varies in accordance with vole populations.

If the body mass variation was linked with the cyclic abundance fluctuations of small voles, being more pronounced in the north $[24,26,27]$, it could be expected that the body mass in northern populations of southern species should vary respectively. In northern populations of common kestrels that are, in contrast to the more stationary southern populations, migratory and largely nomadic vole specialists, the average body mass shows, however, no significant annual variations [21]. Though the tawny owl is a stationary generalist predator $[10,15]$, its breeding in Finland, near the northern limit of the species' range, seems to be considerably affected by the highly fluctuating abundance of small voles [28-31]. On the basis of the results on the Ural owl [20], it could be expected that the variations in food supply would be manifested in the body condition of northern tawny owls as well. Some intrinsic factors may, however, outweigh effects of some extrinsic factors. In tawny owls, female condition is positively influenced by female age and male condition that, in turn, is influenced by male age [19].

The present study examines how the variations in the availability of small voles and alternative prey are reflected in the body condition of breeding females and males of different age in a population of tawny owls in southern Finland, near the northern limit of the species range [31]. In the study area, small voles showed more or less regular oscillations characterised by cycles of three years [32]. Within a year, vole populations also showed drastic seasonal changes, increasing up to the end of the reproductive period (late autumn) and declining up to the beginning of the next one (late spring) [33]. In addition, records show quantitative and qualitative spatial variations in the availability of small voles and alternative prey used by tawny owls [29]. I assume that as generalist predators, tawny owls prey more or less opportunistically upon such suitable prey objects that are available. So, the prey samples from nests should roughly correspond to the availability of prey in the territory.

Based on the data presented above and in other sources I hypothesised as follows.

(1) According to a general rule [4], body condition of breeding tawny owls should decrease during breeding with advancing date, coinciding with the general decline in availability of their staple food (small voles) in early spring before the main reproductive period of voles [33] and with increasing food requirements of the brood $[20,21]$.

(2) Body condition of tawny owls should vary annually with oscillations of small vole populations (see $[8,20]$, cf. $[7,21])$ but the variations should be dampened according to availability of alternative prey $[29,31,34,35]$.

(3) Responses to variations in food supply should differ between sexes according to their different body size and division of roles during breeding $[17,18]$.

\section{Material and Methods}

2.1. Owls. The field study was conducted during 1986-2006 in Uusimaa, near the southern coast of Finland $\left(60^{\circ} \mathrm{N}, 25^{\circ} \mathrm{E}\right)$ [29]. The study area covered about $500 \mathrm{~km}^{2}$, including rural, suburban, and urban subareas. During the study, there were annually more than 300 nest-boxes suitable for tawny owls available evenly throughout the study area. Nest-boxes were of various types, including those turned or hollowed out of stumps of natural tree trunks and those manufactured from board or plywood. The minimum measurements of the boxes accepted by tawny owls were as follows: the width and height of the wall $10 \mathrm{~mm}$ and $45 \mathrm{~cm}$, respectively, the diameter of the nest chamber $25 \mathrm{~cm}$, and that of the entrance hole $12 \mathrm{~cm}$.

Breeding tawny owls (females and males) of the population were captured at nests by hoop net or trap around the middle of the nestling period. Due to the well-known risk of desertion of nest [19], catchings were not performed earlier. Captures occurred mainly in May, but were distributed over a period of more than a hundred days from the first half of March to the last half of June. Each individual was captured only once during each breeding season. The total data (19862006) included 566 encounters concerning 307 individual birds, the respective figures being 346 and 172 for females and 220 and 135 for males.

I sexed the birds on the basis of their size, wing length, body mass, and the prominent incubation patch of the females $[15,17,19]$. I determined the age of birds by the plumage patterns [36]. The age categories included $1 \mathrm{yr}$ old, 2 yrs old, and 3 yrs old or older. The maximum wing length, that is, the distance between the carpal joint and the tip of the longest primary [37], indicated the size of an individual. The body mass (measured by Pesola spring balance to the nearest gram) was used as a measure of body condition [2].

2.2. Food Supply. General oscillations of small vole populations were monitored by annual autumn (October) and spring (May) snap trapping, and an index of number of individuals per 100 trap-nights was set $[32,33]$. This regional indicator of vole abundance combined the numbers of two small vole species, the bank vole Myodes glareolus and field vole Microtus agrestis. Each seasonal index was based on 384 trap-nights: in each standard trapping there were along the catching lines of two localities a total of 64 points with three traps for two successive nights. 
The general role of alternative prey was examined on the basis of regional abundance of wintering birds, the most probable alternative source of food during the early stages of breeding in Finnish tawny owls $[12,31]$. Locally, however, anthropogenic supply of rodents, particularly brown rats Rattus norvegicus, were substantial alternatives [29]. European water voles Arvicola amphibius, the most important prey species of the tawny owl in the later phases of breeding season in southern Finland $[29,35]$ were, in general, out of reach of owls due to their underground living habits during the early stages of breeding season of owls, (e.g, [38]). The winter bird data were derived from the late winter bird censuses arranged by the Finnish Museum of Natural History, University of Helsinki (provided by Väisänen). The winter bird index used included small birds up to the size of the feral pigeon Columba livia that are suitable prey for the tawny owl [29].

Because the regional indices of food abundance might not be representative for the study area [19], and they confined only to two (or three) prey categories, I used the amount and proportion of prey remains left in the nest boxes as a proxy for the overall food supply in the territory that season.

Effects of local food supply on owls was studied on the basis of remains of 3194 prey individuals found in samples taken from 51 owl nests from 30 nesting territories after breeding seasons 1986-1999 (nest bottom samples [29]). From these nests, 66 breeding adults ( 42 females and 24 males, including 21 breeding pairs) were catched and their condition was examined. Food remains were separated from the nest bottom litter by picking the bones, feathers, and so forth, with tweezers and sorted into different categories (including shrews, bank voles, water voles, field voles, mice, rats, birds, and amphibians). In each prey category, the number of individuals was counted on the basis of the most common individual bones found. These samples gave a general picture of the prey used in the nest during breeding. There was a significant correlation between the mean number of field voles in the nests and their regional abundance index in the preceding autumn $\left(r_{s}=0.563\right.$, $P=.044, n=13)$. Similar relationship characterised also small voles in total $\left(r_{s}=0.556, P=.046, n=13\right)$, but in the bank vole alone the relationship was not significant $\left(r_{s}=0.330, P=.261, n=13\right)$.

2.3. Statistical Analyses. Because the food supply was expected to decrease with advancing date from the beginning through the main part of the breeding season [19], the effect of catching date on body condition was considered by inclusion of "the Julian date" expressed as the number of days from the beginning of March each year as an explanatory variable in the analyses. I examined the relationships between the body condition of females and males of different age and their Julian catching day (indicating the seasonal level of food supply) by linear least squares regression analyses. Pearson correlation analysis was used in examining the reflections of variations in single variables of food supply on the condition (body mass) of breeding tawny owls (sexes separated). The regional variables characterised annual level of food supply

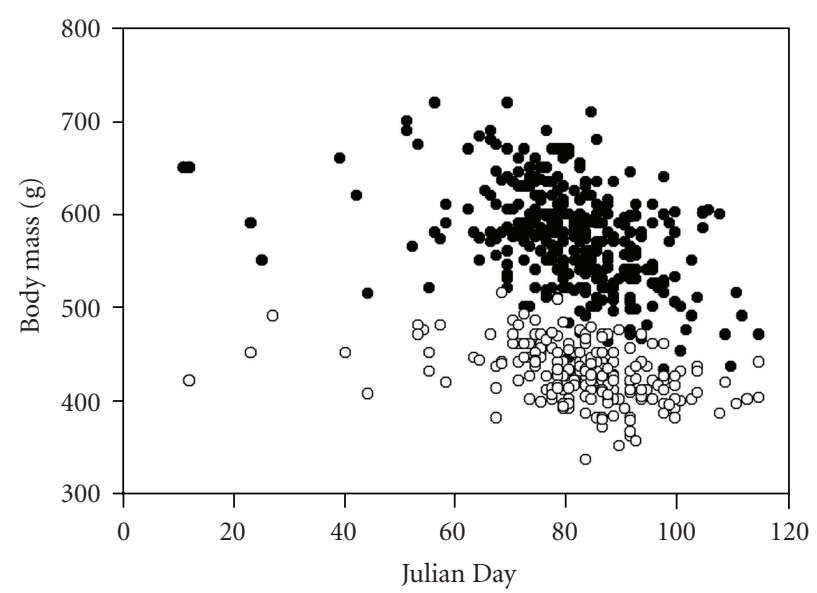

FIgURE 1: The relationship between the body mass (g) and Julian Day (that indicates the seasonal status of prey availability; March $1=$ 0 ) in breeding tawny owl females (black dots) and males (open dots) of the study population in 1986-2006 (linear regression: $t_{1,344}=$ $-8.748, P<.001$ and $t_{1,218}=-6.290, P<.001$, resp., see also Table 1).

and included (1) vole abundance indices of the preceding autumn and concurrent spring (staple prey), and (2) late winter bird index (alternative prey). In addition, the roles of the two small vole species, field vole and bank vole, were examined separately. All these procedures were performed by SigmaStat 3.1 software [39].

In examining the effects of both regional and local food supply on the body condition of the owls that had nested in the boxes from which the prey samples were gathered $(21$ nestings from which both parents, including 17 individual females and 16 males, were caught), I used generalized linear models [40]. I included the following explanatory variables in proper combinations: (1) regional indices of staple food (above), (2) regional index of alternative food (above), (3) numbers and proportions of each local prey category in the nest bottom samples (local availability of food), (4) amount (number and biomass [29]) of total prey per brood (characterising both the foraging capacity and workload of the male), (5) age (characterising experience or skills) of birds, (6) size (indicated by the wing length) of birds (defending capacity of the female and foraging skills of the male), (7) clutch size (increase in energy demands of the female), (8) brood size (amount of stress for the parents, in particular workload of the male), (9) Julian Day of the catching of owls (above), and (10) wing length of the largest nestling in the catching day of the parent (indicator of the stage of breeding). For tentative models, I used only combinations of noncorrelative variables. Best models of significant (or nearly significant) variables were selected in each case primarily on the basis of Akaike Information Criterion (AIC) [41]. If the AICs compared were close to each other (delta AIC less than 2), adjusted coefficients of determination (adj $R^{2}$ ) and the significance of variables included in the models served as selection criteria. 
I performed these analyses by the statistical package nlme in $R[42,43]$.

\section{Results}

3.1. Effects of Seasonal Decline and General Annual Fluctuations in Food Supply. On the population level, the body condition of the tawny owl declined significantly with advancing date (Figure 1) in various age classes of birds in both sexes (Table 1). The Julian Day explained $18.0 \%$ and $15.0 \%$ of the variation in females and males, respectively. When the age of birds was included in the model, the explained variation increased to $29.9 \%$ in females and $25.5 \%$ in males. There was a nearly significant negative relationship between the female (but not male) age and Julian catching day $(r=-0.138, P=.051$, df $=198)$, suggesting that the older females breed earlier than the younger ones. There was no significant correlation between the body condition of breeding tawny owls and the annual regional indices of prey abundance (preceding autumn vole index, spring vole index, winter bird index) neither in females $(r=-0.106-0.081$, $P>.10$, df $=344)$ nor males $(r=-0.081-0.046$, $P>.10$, df $=218)$.

In combination, the age of the individual bird, time of the season (Julian Day), phase of the breeding performance (nestling wing length) in both sexes, and brood size in males explained a considerable proportion of the variation in body condition (Table 2). Based on the regional indices of prey availability, the regional abundance of food showed only minor reflections: bank voles and wintering birds in females and small voles of the preceding autumn in males.

3.2. Effects of Local Food Supply. Based on the local prey samples collected from the nest bottoms, there were no significant relationships between the number of small voles and body condition of tawny owls during the final stage of breeding (Table 3 ). The bird's age, time of the season (Julian Day), and stage of the nestling period (nestling wing length) in both sexes and brood size in males explained much of the variation in the body condition. There was a significant positive relationship between both the number and total biomass of prey individuals remains of which were found in the nest bottom samples and the brood size of tawny owls $(r=0.448, P=.042$ and $r=0.605, P=.004$, df $=19$, resp.). In combination with the above-mentioned variables, the abundance of rats in prey showed a minor but significant contribution to the body condition of females and the abundance of shrews showed a negative relationship with body condition in both sexes. In addition, there were significant or nearly significant correlations between the body condition of owls and the local abundance of some other prey types not entered into the best models presented, including water voles $(r=0.393, P=.078$ in females, $r=0.454, P=.039$ in males, $\mathrm{df}=19)$ and amphibians $(r=-0.399, P=.073$ in females, $r=-0.443, P=$ .044 in males, $\mathrm{df}=19)$ in both sexes, birds in females $(r=$ $0.508, P=.019$, $\mathrm{df}=19)$, and field voles $(r=0.404$, $P=.069, \mathrm{df}=19)$ in males.

\section{Discussion}

The expected seasonal decline in body condition with advancing date was pronounced in both sexes in the tawny owl population studied. Contrary to the expectations, however, there were no significant positive relationships between either the regional or local abundance of small voles and the body condition of owls, the data showing rather some indications of negative relationships. Some alternative prey categories showed also positive relationships. As expected, there were some resemblance but also pronounced differences between sexes in the responses to the variations in food supply. Brood size was originally meant to measure stress having a negative relationship with body condition particularly in males. However, it rather reflected the food supply in the beginning of breeding [19], showing positive relationship with male body condition. Brood size seemed to reflect local food supply even better than regional prey indices.

4.1. Effects of Food Supply. As capital breeders [5], tawny owls, in particular females, should exhibit high body condition before the onset of egg laying. In the beginning of the breeding season (from January to March), the prey species responsible for this in the present study area is mainly the field vole [29], the abundance of which makes early, abundant, and productive breeding of owls possible. Thereafter, the prey availability first decreases with decreasing vole populations [33] before the arrival of migratory birds (in April) and before the beginning of the breeding season of small mammals (in May), and, in particular, before the improved availability of water voles after melting of the snow cover [29]. Because the nest bottom samples were collections of prey through the whole annual breeding periods of owls, the proportions of small voles were higher and those of alternative prey lower than they should be for the nestling period considered here. Thus, the effect of small voles on the condition of owls during that period should be lower and that of alternative prey higher than suggested by the present results.

The present results suggest that the body condition of breeding tawny owls during the final stage of breeding in southern Finland was not significantly affected by the general abundance of small voles. This finding was consistent with both the regional and local indicators of vole abundance (cf. also [35]). Probably small voles were, however, of considerable importance around the onset of egg laying, but later in the season their significance seemed to decrease [29]. The general level of abundance in small voles, particularly in field voles, seemed to have decreased during the study period $[33,44]$, and the vulnerability of various kinds of prey to predation during winter, and that of water voles during the early stages of breeding of owls, has probably increased due to the minor snow cover of the recent mild winters, increasing the proportion of alternative prey. Thus, the lack of significant relationships between the abundance of small voles and body condition in tawny owls in the present study may also be at least partly due to the late phase of breeding (around the middle of the nestling period) considered, and 
TABLE 1: Linear regression models explaining the relationships between the condition (body mass, $g$ ) of breeding tawny owls of different sex and age and the Julian Day of the bird catching (indicating the seasonal status of prey availability). The age classes are young $(<3 \mathrm{yr})$ and old ( $\geq 3 \mathrm{yr}$ ) individuals, or (in the last two models) 1,2 , or 3 (or more) years. Formulas, coefficients of determination $\left(R^{2}\right)$, test statistics $(t$, or $F$ in last two models), degrees of freedom (df), and $P$ values are given.

\begin{tabular}{|c|c|c|c|c|}
\hline Formula & $R^{2}$ & $t / F$ & df & $P$ \\
\hline Female body mass $=7144.248-(17.363 *$ Julian Day $)$ & 0.180 & -8.748 & 1,244 & $<.001$ \\
\hline Male body mass $=4979.046-(8.612 *$ Julian Day $)$ & 0.150 & -6.290 & 1,218 & $<.001$ \\
\hline Young female body mass $=689.104-(1.727 *$ Julian Day $)$ & 0.198 & -4.012 & 1,60 & $<.001$ \\
\hline Old female body mass $=731.642-(1.885 *$ Julian Day $)$ & 0.238 & -6.623 & 1,136 & $<.001$ \\
\hline Young male body mass $=481.609-(0.884 *$ Julian Day $)$ & 0.081 & -2.338 & 1,50 & .023 \\
\hline Old male body mass $=480.426-(0.589 *$ Julian Day $)$ & 0.108 & -4.334 & 1,146 & $<.001$ \\
\hline Female body mass $=677.704-(1.861 *$ Julian Day $)+(17.039 *$ Female age $)$ & 0.299 & 43.501 & 2,197 & $<.001$ \\
\hline Male body mass $=430.333-(0.616 *$ Julian Day $)+(17.554 *$ Male age $)$ & 0.255 & 34.549 & 2,197 & $<.001$ \\
\hline
\end{tabular}

TABLE 2: The best generalized linear models showing the most significant relationships between the regional prey indices and body condition in breeding tawny owls. Other factors probably related to body condition were also included in the preliminary analyses. Estimates, standard errors (SE), test statistics $(t)$, and their significance $(P)$ as well as adjusted coefficients of determination for each single variable $\left(\right.$ Adj $\left.r^{2}\right)$ and the difference between adjusted coefficients of determination of subsequent variables in the model $\left(\Delta\right.$ Adj $\left.R^{2}\right)$ are given. For total models, test statistics $(F)$, their significance $(P)$, and adjusted coefficients of determination (Adj $\left.R^{2}\right)$ are presented.

\begin{tabular}{lccccc}
\hline Variable & Estimate & SE & $t_{1,19} / F_{5,15}$ & $P$ & ${\text { Adj } r^{2}}$ \\
\hline Females & & & & & \\
$\quad$ Intercept) & 952.013 & 78.765 & 12.087 & $<.001$ & 0.361 \\
Nestling wing length & -0.900 & 0.247 & -3.643 & .002 & 0.179 \\
Julian Day & -4.154 & 1.015 & -4.092 & .001 & 0.117 \\
Age of bird & 28.823 & 9.428 & 3.057 & .008 & -0.052 \\
Spring bank voles & -38.089 & 13.070 & -2.914 & .011 & -0.051 \\
Winter birds & 0.001 & 0.001 & 1.907 & .076 & 0.107 \\
\hline Total model & & 12.22 & $<.001$ & 0.083 \\
\hline Males & & & & 0.043 \\
$\quad$ Intercept) & 466.598 & 37.268 & 12.520 & $<.001$ & 0.737 \\
Julian Day & -1.232 & 0.334 & -3.689 & .002 & 0.389 \\
Age of bird & 22.883 & 4.642 & 4.930 & $<.001$ & 0.308 \\
Autumn voles & -2.050 & 0.770 & -2.662 & .018 & -0.053 \\
Nestling wing length & -0.278 & 0.085 & -3.254 & .005 & 0.041 \\
Brood size & 12.281 & 4.714 & 2.605 & .020 & 0.389 \\
\hline Total model & & 25.81 & $<.001$ & 0.020 \\
\hline
\end{tabular}

the situation may be largely different in the early phases of breeding (cf. [20]). During the later phases of breeding, water voles were the most important prey for maintaining body condition of males and birds for condition of females. The abundance of these prey types indicates, in general, territories of rich and fertile habitats near wetlands, preferred by Finnish tawny owls [31].

Negative relationships between prey indices and body condition of owls suggest that such prey is not profitable enough to maintain a steady level of body mass. The negative relationship between the abundance of prey type and body condition of owls could mean that if the male delivers a lot of less profitable prey such as shrews it leads to small biomass of food in the nest, meaning that the food supply of the territory is poor, or male hunting effort or success is poor. In general, foraging males seemed to be able to help their mates to maintain sufficient body condition regardless of the local level of the abundance of field voles, relying on the more stable basic food supply of the territory, such as birds, water voles, and rats. The abundant use of bird prey indicated high-quality territories of good basic food supply, in particular from the point of view of body condition of female tawny owls. In poor feeding conditions of territories of lower basic food level, the lack of small voles and birds was largely compensated by shrews and frogs that were, however, not enough to maintain the body condition of owls.

The improved body condition of males before the breeding season due to the abundance of field voles probably makes breeding possible in vole peak years even in such localities where the basic food supply is too scanty for breeding. For the long-term occupancy of territories, the year-round food resources should be high enough for maintaining at least the body condition of adult birds even in poor vole years. The local variation in the food base 
TABLE 3: The best generalized linear models showing the relationships between the local food supply and body condition in breeding tawny owls. Other factors probably related to body condition were also included in the preliminary analyses. Estimates, standard errors (SE), test statistics $(t)$, and their significance $(P)$ as well as adjusted coefficients of determination for each single variable (Adj $\left.r^{2}\right)$ and the difference between adjusted coefficients of determination of subsequent variables in the model ( $\left.\Delta \operatorname{Adj} R^{2}\right)$ are given. For total models, test statistics $(F)$, their significance $(P)$, and adjusted coefficients of determination $\left(\operatorname{Adj} R^{2}\right)$ are presented.

\begin{tabular}{|c|c|c|c|c|c|c|}
\hline Variable & Estimate & $\mathrm{SE}$ & $t_{1,19} / F_{5,15}$ & $P$ & Adj $r^{2}$ & $\Delta \operatorname{Adj} R^{2}$ \\
\hline \multicolumn{7}{|l|}{ Females } \\
\hline (Intercept) & 845.866 & 53.709 & 15.749 & $<.001$ & & \\
\hline Nestling wing length & -1.208 & 0.208 & -5.819 & $<.001$ & 0.361 & 0.361 \\
\hline Julian Day & -2.473 & 0.585 & -4.224 & $<.001$ & 0.179 & 0.107 \\
\hline Age of bird & 25.104 & 8.478 & 2.961 & .009 & 0.117 & 0.143 \\
\hline Rats in prey & 15.229 & 4.106 & 3.709 & .002 & -0.052 & 0.106 \\
\hline Shrews in prey & -2.226 & 0.853 & -2.609 & .020 & 0.070 & 0.075 \\
\hline Total model & & & 16.26 & $<.001$ & & 0.792 \\
\hline \multicolumn{7}{|l|}{ Males } \\
\hline (Intercept) & 419.484 & 32.382 & 12.954 & $<.001$ & & \\
\hline Brood size & 12.762 & 4.493 & 2.840 & .012 & 0.410 & 0.410 \\
\hline Shrews in prey & -0.966 & 0.315 & -3.070 & .008 & 0.259 & 0.182 \\
\hline Nestling wing length & -0.234 & 0.080 & -2.941 & .010 & 0.041 & 0.126 \\
\hline Age of bird & 21.414 & 4.522 & 4.735 & $<.001$ & 0.308 & 0.116 \\
\hline Julian Day & -0.794 & 0.318 & -2.496 & .025 & 0.389 & 0.041 \\
\hline Total model & & & 28.86 & $<.001$ & & 0.875 \\
\hline
\end{tabular}

between territories probably largely masked the effects of annual abundance fluctuations of small voles. In poor vole years, tawny owls seemed to breed only in the most suitable territories of relatively high and stable food supply [29]. Thus, particularly in such years, birds occupying the poorest territories and probably being in the poorest condition were not included in the present data of successfully breeding birds.

The present results suggest that local environmental conditions, in particular local prey supply, and individual characteristics of males were strongly involved in determining body condition in tawny owls (cf. $[18,45,46])$. Breeding is probably a comprehensively strenuous duty for the body condition of males [7, 13, 17], while in females condition first increases before the onset of egg laying and then declines during breeding $[4,14,20]$ at a rate determined by the local availability of food and foraging capacity of the male.

From the individual point of view, the seasonal decline of food supply means that due to decreasing resources the body condition of birds decreases, and it is harder and it takes increasingly longer for the male to fatten the female to breeding condition. From the population point of view, this means that breedings shift later and the later clutches are smaller than the earlier ones [47]. High levels of staple food (small voles) in the beginning of breeding season generate high body condition in owls and allow early and rapid fattening of females to breeding condition, large clutches, and many pairs to breed. When the levels of staple food are low, the body condition of owls is low already in the beginning of the breeding season, and it is hard and takes long for the male to fatten the female to breeding condition, clutches are small, and only relatively few pairs are able to breed.
4.2. Interspecific Comparisons. Tawny owls seemed to differ from the closely related Ural owl females, the body condition of which clearly varies in accordance with cyclic vole populations [20]. Tawny owls of temperate origin seemed to have adapted to a temporally more stable food supply than Ural owls of the boreal taiga. The body condition of Ural owl females varies more in good than in intermediate breeding seasons $[48,49]$. Similar patterns characterise the breeding of tawny owls [29, 31, 50]. It suggests that in good vole years various kinds of individuals, including young and unexperienced ones, are able to breed, and various habitats are occupied by breeding birds, while in poorer seasons the breeding population mainly consists of birds that occupy the relatively sparse territories of the highest basic food supply. In general, tawny owls probably skip breeding before the body condition begins to decline due to the decreasing food supply. In Ural owls this threshold seemed to be relatively higher than in tawny owls. The verification of these hypotheses needs, however, a sufficient sample of measurements of individuals ascertained as nonbreeders.

Of the nomadic vole specialists, Tengmalm's owls [8] seemed to follow the Siberian body mass variation pattern of Ural owls, whereas common kestrels [21] resemble tawny owls, following the European one. These patterns thus reflect the faunistic origin of the species [51]. These characteristics also fit well the known history of the Finnish populations of the species. The Ural owl and Tengmalm's owl are old inhabitants of the western taiga in Finland [52], while the tawny owl is a relatively recent southern colonist since a good hundred years $[31,52]$. After a deep crash during the last few decades, the Finnish common kestrel population is at present rapidly increasing $[12,52]$, probably beginning with considerable recruitment from southern immigrants. 


\section{Conclusions}

The present results suggest that the primary body condition of breeding tawny owls in the beginning of the breeding season in southern Finland is largely determined by the abundance of their staple prey, field voles. This resource first diminishes but later in spring the general food availability increases when migratory birds arrive and water voles become available as snow cover melts. Then the role of alternative prey in keeping the body condition of owls appropriate increases towards the end of the breeding season at least until reproduction begins to recover also the depleted field vole populations.

From the individual point of view, the general decline of body condition through the early phases of breeding season is probably due to a general decrease in food supply during this period of time, and, from the population point of view, also because the most competent birds in the best body condition are among the earliest breeders.

As far as can be deduced from the present data, feeding males could maintain a tolerable body condition in breeding females regardless of general regional level of food by relying on the local basic food supply of the territory. Thus, in the most suitable territories, breeding of owls was possible year after year in spite of the considerable oscillations of small vole populations.

\section{Acknowledgments}

The field work was helped by many people, including Atte Bonsdorff, Johan Bäckström, Seppo Jäppilä, Jonna Karhunen, Jorma Kohonen, Kai Kuusisto, Risto Pekkarinen, Esa Pienmunne, Jari Pynnönen, Rainer Salo, Klaus Silfverberg, Jorma Turunen, Kimmo af Ursin, Jarmo Vajesoja, and Bengt Ådahl. Jonna Karhunen analysed the nest bottom samples. Throughout the project the support of the author's family has been indispensable. Hannu Pietiäinen and some anonymous referees read a draft of the manuscript and made useful suggestions. The owl nests were visited with permits from the Finnish Ministry of the Environment. The birds were handled according to accepted guidelines.

\section{References}

[1] C. R. Blem, "Avian energy storage," in Current Ornithology, D. M. Power, Ed., vol. 7, pp. 59-113, Plenum Press, New York, NY, USA, 1990.

[2] J. L. Schamber, D. Esler, and P. L. Flint, "Evaluating the validity of using unverified indices of body condition," Journal of Avian Biology, vol. 40, no. 1, pp. 49-56, 2009.

[3] E. Lehikoinen, "Is fat fit? A field study of survival and fatness in the great tit Parus major L.," Ornis Fennica, vol. 63, pp. 112 119, 1986.

[4] R. E. Ricklefs, "Energetics of reproduction in birds," in Avian Energetics, R. A. Paynter Jr., Ed., pp. 152-292, Nuttall Ornithological Club, Cambridge, Mass, USA, 1974.

[5] R. H. Drent and S. Daan, "The prudent parent: energetic adjustments in avian breeding," Ardea, vol. 68, pp. 225-252, 1980.
[6] K. I. Jönsson, "Capital and income breeding as alternative tactics of resource use in reproduction," Oikos, vol. 78, no. 1, pp. 57-66, 1997.

[7] G. J. M. Hirons, "The importance of body reserves for successful reproduction in the tawny owl (Strix aluco)," Journal of Zoology (London) B, vol. 1, pp. 1-20, 1985.

[8] E. Korpimäki, “Body mass of breeding Tengmalm's owls Aegolius funereus: seasonal, between-year, site and age-related variation," Ornis Scandinavica, vol. 21, no. 3, pp. 169-178, 1990.

[9] A. Lundberg, "Residency, migration and a compromise: adaptations to nest-site scarcity and food specialization in three fennoscandian owl species," Oecologia, vol. 41, no. 3, pp. 273-281, 1979.

[10] H. Mikkola, Owls of Europe, Poyser, Calton, UK, 1983.

[11] E. Korpimäki, "Niche relationships and life-history tactics of three sympatric Strix owl species in Finland," Ornis Scandinavica, vol. 17, no. 2, pp. 126-132, 1986.

[12] T. Solonen, "Breeding of Finnish birds of prey in relation to variable winter food and weather conditions," Memoranda Societatis pro Fauna et Flora Fennica, vol. 81, no. 1, pp. 19-31, 2005.

[13] H. N. Southern, "The natural control of a population of tawny owls (Strix aluco)," Journal of Zoology (London), vol. 162, pp. 197-285, 1970.

[14] I. Newton, Population Ecology of Raptors, Poyser, Berkhamstead, UK, 1979.

[15] S. Cramp, Handbook of the Birds of Europe, the Middle East and North Africa. The Birds of the Western Palearctic, vol. 4, Oxford University Press, Oxford, UK, 1985.

[16] T. Meijer, S. Daan, and M. Hall, "Family planning in the kestrel (Falco tinnunculus): the proximate control of covariation of laying date and clutch size," Behaviour, vol. 114, no. 1-4, pp. 117-136, 1990.

[17] P. Sunde, M. S. Bølstad, and J. D. Møller, "Reversed sexual dimorphism in tawny owls, Strix aluco, correlates with duty division in breeding effort," Oikos, vol. 101, no. 2, pp. 265-278, 2003.

[18] M. Andersson and R. Å. Norberg, "Evolution of reversed sexual size dimorphism and role partitioning among predatory birds, with a size scaling of flight performance," Biological Journal of the Linnean Society, vol. 15, no. 2, pp. 105-130, 1981.

[19] T. Solonen, "Factors affecting reproduction in the tawny owl Strix aluco in southern Finland," Annales Zoologici Fennici, vol. 46, no. 4, pp. 302-310, 2009.

[20] H. Pietiäinen and H. Kolunen, "Female body condition and breeding of the Ural owl Strix uralensis," Functional Ecology, vol. 7, no. 6, pp. 726-735, 1993.

[21] K. I. Jönsson, J. Wiehn, and E. Korpimäki, "Body reserves and unpredictable breeding conditions in the Eurasian kestrel, Falco tinnunculus," Écoscience, vol. 6, no. 3, pp. 406-414, 1999.

[22] A. Village, "Body weights of Kestrels during the breeding cycle," Ringing and Migration, vol. 4, pp. 167-174, 1983.

[23] C. Dijkstra, S. Daan, T. Meijer, A. J. Cavé, and R. P. B. Foppen, "Daily and seasonal variations in body mass of the Kestrel in relation to food availability and reproduction," Ardea, vol. 76, pp. 127-140, 1988.

[24] L. Hansson and H. Henttonen, "Gradients in density variations of small rodents: the importance of latitude and snow cover," Oecologia, vol. 67, no. 3, pp. 394-402, 1985.

[25] J. R. Krebs and N. B. Davies, An Introduction to Behavioural Ecology, Blackwell, Oxford, UK, 1993. 
[26] N. C. Stenseth, "Population cycles in voles and lemmings: density dependence and phase dependence in a stochastic world," Oikos, vol. 87, no. 3, pp. 427-461, 1999.

[27] J. Sundell, O. Huitu, H. Henttonen et al., "Large-scale spatial dynamics of vole populations in Finland revealed by the breeding success of vole-eating avian predators," Journal of Animal Ecology, vol. 73, no. 1, pp. 167-178, 2004.

[28] P. Linkola and A. Myllymäki, "Der Einfluss der Kleinsäugerfluktuationen auf das Brüten einiger kleinsäugerfressender Vögel im südlichen Häme, Mittelfinnland 1952-1966," Ornis Fennica, vol. 46, pp. 45-78, 1969.

[29] T. Solonen and J. Karhunen, "Effects of variable feeding conditions on the Tawny Owl Strix aluco near the northern limit of its range," Ornis Fennica, vol. 79, no. 3, pp. 121-131, 2002.

[30] C. M. Francis and P. Saurola, "Estimating components of variance in demographic parameters of Tawny Owls, Strix aluco," Animal Biodiversity and Conservation, vol. 27, no. 1, pp. 489-502, 2004.

[31] T. Solonen, "Breeding of the Tawny Owl Strix aluco in Finland: responses of a southern colonist to the highly variable environment of the North," Ornis Fennica, vol. 82, no. 3, pp. 97-106, 2005.

[32] T. Solonen and P. Ahola, "Intrinsic and extrinsic factors in the dynamics of local small-mammal populations," Canadian Journal of Zoology, vol. 88, no. 2, pp. 178-185, 2010.

[33] T. Solonen, "Overwinter population change of small mammals in southern Finland," Annales Zoologici Fennici, vol. 43, no. 3, pp. 295-302, 2006.

[34] L. Sasvári, Z. Hegyi, T. Csörgó, and I. Hahn, "Age-dependent diet change, parental care and reproductive cost in tawny owls Strix aluco L.," Acta Oecologica, vol. 21, no. 4-5, pp. 267-275, 2000.

[35] J. Kekkonen, H. Kolunen, H. Pietiäinen, P. Karell, and J. E. Brommer, "Tawny owl reproduction and offspring sex ratios under variable food conditions," Journal of Ornithology, vol. 149, no. 1, pp. 59-66, 2008.

[36] S. J. Petty, "A guide to age determination of Tawny Owl Strix aluco," in The Ecology and Conservation of European Owls, C. A. Galbraicht, I. R. Taylor, and S. Percival, Eds., pp. 8991, Joint Nature Conservation Committee, Peterborough, UK, 1992.

[37] R. Spencer, The Ringer's Manual, BTO, Oxford, UK, 2nd edition, 1972.

[38] S. P. Carter and P. W. Bright, "Reedbeds as refuges for water voles (Arvicola terrestris) from predation by introduced mink (Mustela vison)," Biological Conservation, vol. 111, no. 3, pp. 371-376, 2003.

[39] Systat, SigmaStat 3.1. User's Manual, Systat Software, Point Richmond, Calif, USA, 2004.

[40] W. N. Venables and B. D. Ripley, Modern Applied Statistics with S, Springer, New York, NY, USA, 2002.

[41] K. Burnham and D. Anderson, Model Selection and Multimodel Inference: A Practical Information-Theoretic Approach, Springer, New York, NY, USA, 2nd edition, 2002.

[42] R Development Core Team, " $R$ : a language and environment for statistical computing. R foundation for statistical computing," Vienna, Austria, 2008, http://www.R-project.org .

[43] W. N. Venables, D. M. Smith, and R Development Core Team, "An introduction to R. Version 2.8.0.- the R project for statistical computing," 2008, http://www.r-project.org .

[44] T. Solonen, "Are vole-eating owls affected by mild winters in southern Finland?" Ornis Fennica, vol. 81, no. 2, pp. 65-74, 2004.
[45] C. M. Earhart and N. K. Johnson, "Size dimorphism and food habits of North American owls," Condor, vol. 72, pp. 251-264, 1970.

[46] A. Hedenström, "Flight performance in relation to fuel load in birds," Journal of Theoretical Biology, vol. 158, no. 4, pp. 535537, 1992.

[47] S. Daan, C. Dijkstra, and J. M. Tinbergen, "Family planning in the kestrel (Falco tinnunculus): the ultimate control of covariation of laying date and clutch size," Behaviour, vol. 114, no. 1-4, pp. 83-116, 1990.

[48] H. Pietiäinen, P. Saurola, and R. A. Väisänen, "Parental investment in clutch size and egg size in the Ural owl Strix uralensis," Ornis Scandinavica, vol. 17, pp. 309-325, 1986.

[49] H. Pietiäinen, "Breeding season quality, age, and the effect of experience on the reproductive success of the Ural owl (Strix uralensis)," Auk, vol. 105, pp. 316-324, 1988.

[50] P. Karell, K. Ahola, T. Karstinen, A. Zolei, and J. E. Brommer, "Population dynamics in a cyclic environment: consequences of cyclic food abundance on tawny owl reproduction and survival," Journal of Animal Ecology, vol. 78, no. 5, pp. 10501062, 2009.

[51] K. H. Voous, Atlas of European Birds, Helson, London, UK, 1960.

[52] R. A. Väisänen, E. Lammi, and P. Koskimies, Distribution, Numbers and Population Changes of Finnish Breeding Birds, Otava, Helsinki, Finland, 1998. 

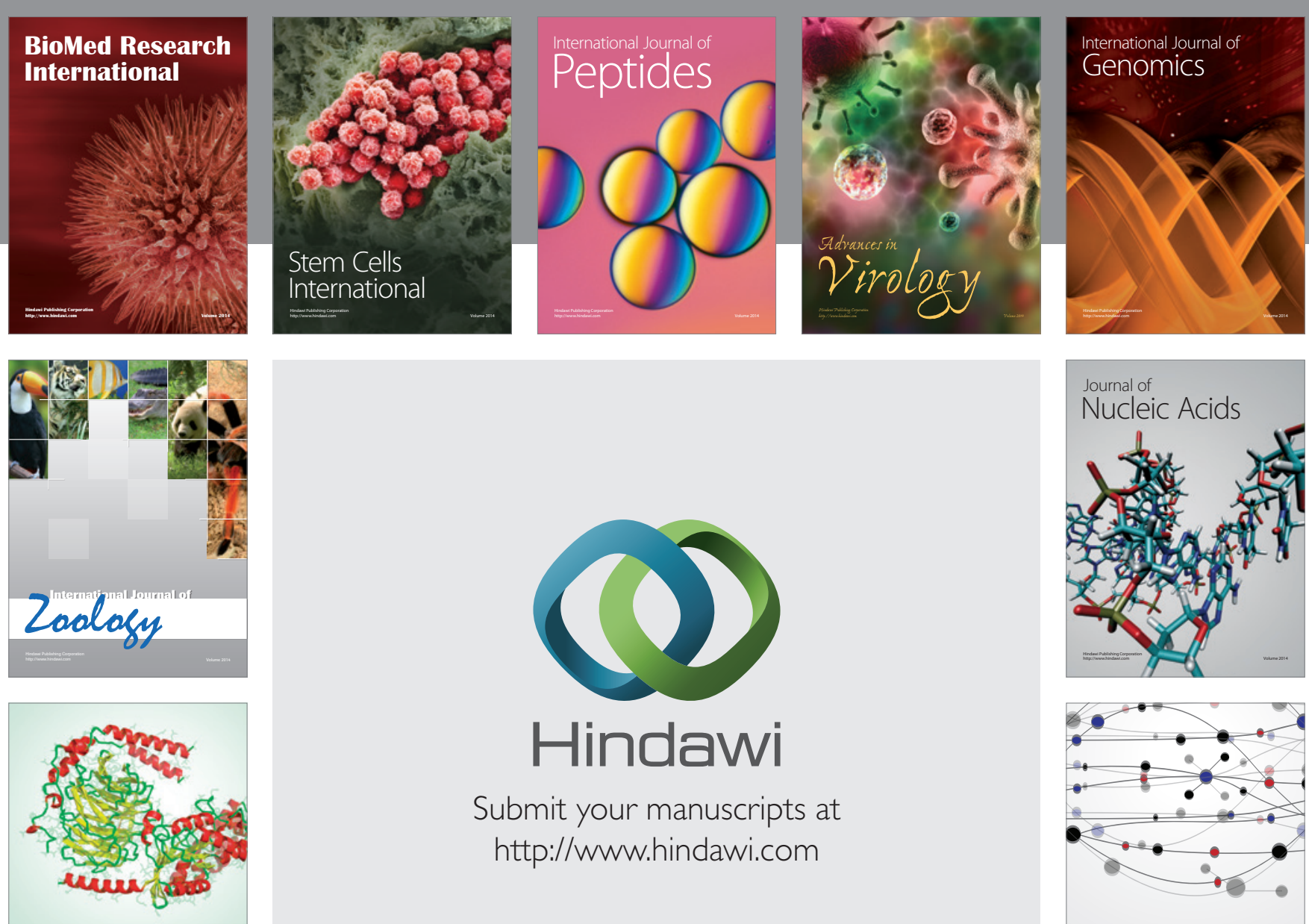

Submit your manuscripts at

http://www.hindawi.com

Signal ${ }^{\text {Jumal }}$ Transduction
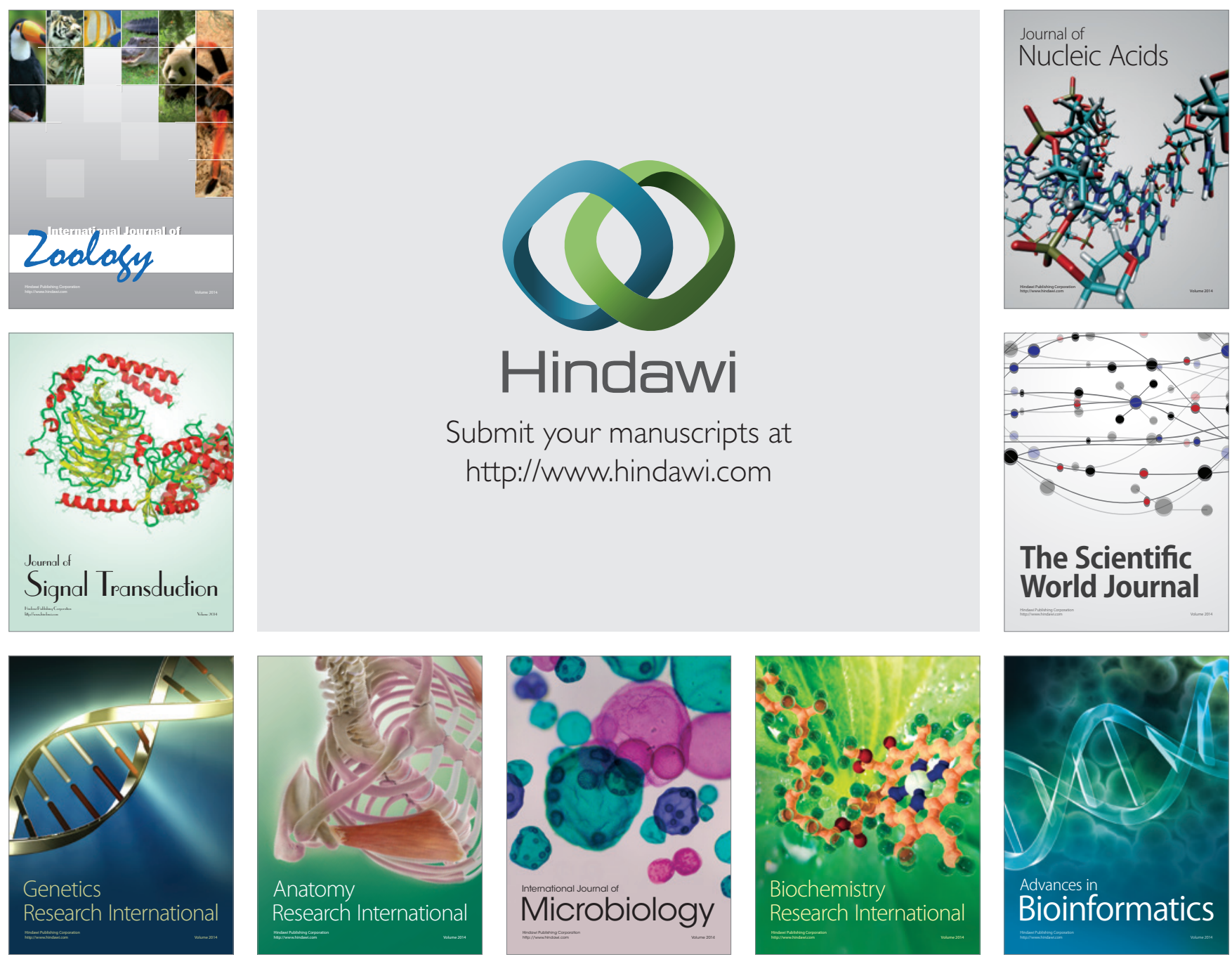

The Scientific World Journal
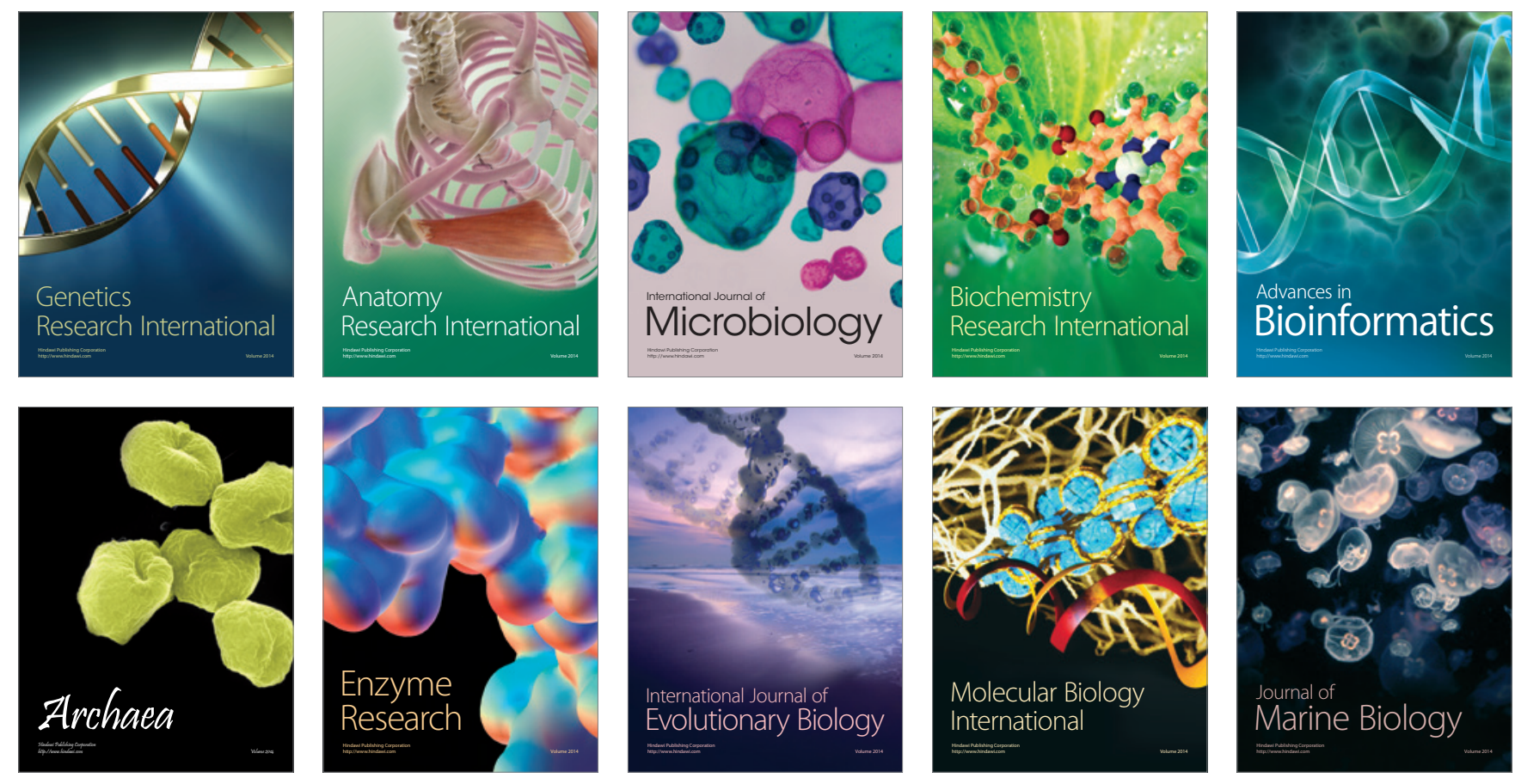